\title{
A QUASI-EXPERIMENTAL EVALUATION OF TUITION REIMBURSEMENT IN MUNICIPAL GOVERNMENT
}

\author{
Helen Weems Daley \\ Research Associate \\ Dade County, Florida \\ Ronald D. Sylvia \\ Department of Political Science \\ University of Oklahoma
}

\begin{abstract}
An evaluation of the tuition reimbursement program for a mid-sized mid-Atlantic city was undertaken using both surveys and quasi-experimental techniques. Contrary to recent criticisms of tuition reimbursement programs, the survey findings indicate generally perceived benefits of the program among participants, supervisors and non-participant co-workers. The quasi-experimental phase of the research determined a $56 \%$ higher promotion rate among participants than among non-participants; moreover, program participants were much more likely to remain in city employment than were non-participants.
\end{abstract}

\section{Introduction}

There are two pervasive themes in the current literature of public administration. One theme calls for an upgrading of the quality of public service by means of increased professionalism. To accomplish this end, governments at all levels have emphasized training programs. Organizations with extensive personnel resources may conduct in-house training programs tailored to the needs of the organization. A more common approach, however, is to encourage employees to seek professional development on their own time and to provide reimbursement for tuition expenses when the contents of the course are judged relevant to the individual's job by his or her supervisor. As a general rule, managers have broadly interpreted course relevance to the point where some employees have obtained advanced professional degrees by means of tuition assistance programs.

The second theme in the literature seeks ways of achieving economy and efficiency in government. This theme is in part traditional insofar as it is consistent with the American value of less government being better government. Of late, however, professional administrators have experienced demands for increased services, shrinking tax bases and spiralling inflation. In the face of these realities, administrators seek to make systematic choices between programs which may all be of value.

Pesonnel programs generally and professional development programs in 
particular are likely to come under meticulous scrutiny when a city begins to engage in cutback management. There are two reasons for this. First, such programs have no specific constituency in the commurity. Second, professional development programs are justiffed only on the basis of their general contribution to better govermment. More systematic and direct benefits must be demonstrated if professional development programs are to survive the current era of cutback management.!

What follows is an empirical examination of one tuition assistance program using a quasi-experimental design. ${ }^{2}$ In addition to examining the one-10-one benefits of the program, the study assessed employee perceptions of the program vis-a-vis other fringe benefits including insurance, payments of professional dues and parking.

The literature of personnel administration suggests that tuition reimbursement benefits the organization; (a) by providing employees with the opportunity to upgrade their job skills; (b) that tuition reimbursement is a valuable non-taxable form of employee compensation; and (c) when used effectively, such programs improve employee relations (Ling, 1965). Organized labor also has recognized tuition reimbursement as a valuable fringe benefit (Foegen, 1973).

Studies by the National Industrial Conference Board have supported the positive image of tuition reimbursement programs. These studies indicate that organizations have generally been satisfied with the return on their investment. Respondents to the surveys indicated that the programs provided a pool of qualified persons for internal promotion, improved employee relations and that, as a result of the programs, the organization was better able to compete (Conference Board, 1956). The more recent surveys indicate that organizations are increasing their reimbursement investments and liberalizing the range of topics eligible for reimbursement under the program (Seybold, 1970).

The findings of the Industrial Relations Board Survey do not indicate whether the organizations in question undertook to empirically tesi their programs or if the survey responses were based solely upon opinion. The City of Milwaukee did survey its employees to determine the value of its reimbursement program. The findings indicated that the principal reasons for participating were job development, achieving promotion and keeping up with one's field. Supervisors also believed the program was beneficial. Finally, more than $70 \%$ of the employees who participated indicated that they had been promoted at least once. These data, however, were not compared with non-participants' data to determine relative rates of advancement (Milwaukee Training Unit, 1977).

Despite all the favorable commentary on tuition reimbursement, some serious questions have been raised by Kaimen and Robey (1976). In addition to the direct costs of the program, 炎aimen and Robey cite the possibility of 
indirect costs which may include secretaries typing papers for students, students studying for exams on company time, and failure of the studentemployee to concentrate on the job.

More importantly, Kaimen and Robey raise the aspect of increased perception of self-worth to the organization on the part of the studentemployee. If increased rewards do not follow participation, the dissatisfied student-employee may well leave the organization. If tuition assistance is to survive economy measures, program defenders must demonstrate direct benefits to the organization, must demonstrate that the program does not produce the sorts of negative secondary outcomes cited by Kaimen and Robey, and that the program is viewed as worthwhile in relation to other programs as well as being intrinsically valuable. In light of the above, the current study sought to address the following research questions.

1. To what degree does participation affect job performance?

2. What is the relative value placed upon the program by employees vis-a-vis other benefits?

3. Is participation in such programs related to the decision to remain with or leave the organization?

4. To what degree is participation in the program related to rates of promotion in the organization?

\section{The Study}

The subjects of this study were a stratified random sample of employees of a mid-sized mid-Atlantic city. Sixty employees, stratified for pay grade, were selected at random from among persons who had participated in the reimbursement program. These persons were matched with sixty nonparticipants on the basis of pay grade. In addition, twenty randomly selected supervisors were also surveyed.

In this organization, the tuition reimbursement may be used for job related education - relatedness is determined by the persons' supervisor. In the two years prior to the evaluation, an average of 172 employees per year took advantage of the program at a cost of $\$ 83.00$ per participant. The total cost per year averaged $\$ 14,302.81$ for the past two years.

To address the first two research questions, thirty participants, thirty nonparticipants and twenty randomly selected supervisors were surveyed. To answer the latter two questions the sixty participants in the program were divided into two subgroups of thirty each. Two matched subgroups of thirty non-participants were also selected. The personnel records of each subgroup were then examined with regard to termination of city employment and rates of promotion. 


\section{Finding}

The first research question addresses the concern for the impact of program participation upon job performance. Thirty participants, thirty nonparticipants and twenty supervisors were asked "Does participation in the turion reimbursement program cause the participant's work to suffer?"

TABLE

Summary of 'Subjects' Perceptons of the Tumon Relmbursentent

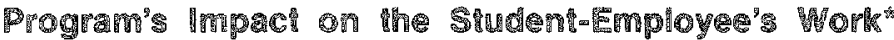

\begin{tabular}{|c|c|c|}
\hline & \multicolumn{2}{|c|}{ 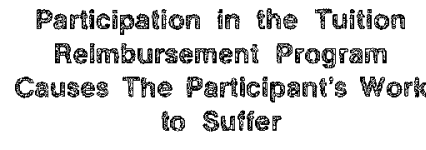 } \\
\hline & Yes & No \\
\hline Participants & $2(9 \%)$ & $21(91 \%)$ \\
\hline Non-Participants $\ldots . . \ldots \ldots \ldots \ldots$ & $6(27 \%)$ & $16(73 \%)$ \\
\hline$\cdots \cdots \cdots \mu_{1}$ & $1(6 \%)$ & $17(94 \%)$ \\
\hline
\end{tabular}

"Figure does not include non-responses.

The figures in Table $\mathbb{1}$ are revealing. Neither participants nor supervisors believe that participation adversely affects the work of participants. The subjectivity of the participants is granted; however, supervisors do not perceive program participation negatively either. Twenty-seven percent of non-participant co-workers do believe that work suffers as a result of participation. The difference, however, was not significant; therefore, the notion of an adverse effect of participation on performance does not appear to be valid for the city in question.

The benefits of the program are illustrated in Table 2, which reflects the respondents' opinion regarding job improvement as a result of program participation. 
TABLE 2

Summary of Subjects' Perceptions with Regard to the Use of Courses in Helping to Improve Job Performance*

\begin{tabular}{|c|c|c|}
\hline & Improve $J$ & Performance \\
\hline & Yes & No \\
\hline Participants & $20(87 \%)$ & $3(13 \%)$ \\
\hline Non-Participants ... & $17(81 \%)$ & $4(19 \%)$ \\
\hline Supervisors ...... & $16(94 \%)$ & $1(6 \%)$ \\
\hline
\end{tabular}

*Figure does not include non-responses.

Participants, non-participant co-workers and supervisors all agree that job performance improves as a result of participation. The percentage of positive opinions among supervisors and co-workers is lower than among participants, but not significantly. The fact that $87 \%$ of the participants believe that the program helped them improve their job performance is particularly reinforcing for the continuation of the program.

The second research question sought to determine the value placed upon tuition reimbursements compared to other fringe benefits. To accomplish this the subjects were asked to rank-order the importance of five benefits with 1 indicating least important and 5 indicating most important. The five benefits were hospitalization insurance, retirement, employee parking, tuition reimbursement and the payment of professional dues. 


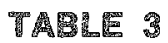
Mean Ranking of the Importance of Cortain Finployer

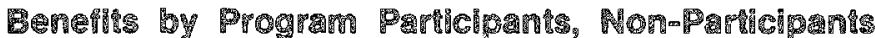 and Supervisors

\begin{tabular}{|c|c|c|c|}
\hline & \multicolumn{3}{|c|}{ Survey Group Responses } \\
\hline & Paricipants & $\begin{array}{c}\text { Mor- } \\
\text { Partetpants }\end{array}$ & Supervisors \\
\hline Insurance (hosp.) & 4.61 & 4.64 & 4.26 \\
\hline Retirement $\ldots . . . . . . . . . .$. & 4.52 & 4.59 & 4.58 \\
\hline Employee Parking & 2.74 & 2.91 & 2.32 \\
\hline Tuition Reimbursement & 3.26 & 2.64 & 2.84 \\
\hline Payment of Professional Dues & 1.91 & 2.18 & 1.80 \\
\hline
\end{tabular}

As expected, insurance and retirement ranked one and two for all three groups. Tuition reimbursement, however, was ranked ahead of employee parking and the payment of professional dues by program participants and supervisors. Parking was ranked more important by non-participants than reimbursement. Although the differences between groups were not significant, the distinction is still worthy of elaboration. The city in question is in a highly urbanized area; city hall is downtown and recent urban renewal projects have placed a premium on downtown parking. The value of the program in the minds of participants and supervisors is reflected in their preference for the program over free parking - albeit a non-significant preference.

As previously noted, two matched groups of sixty persons each were selected on a stratified ramdom basis from participants and non-participants. These groups were further divided into subgroups of thirty each to examine research questions 3 and 4 .

The personnel records of thirty program participants and a matched group of thirty non-participants were examined with regard to tumover rates. 
TABLE

Employee Tumover of Tuition Reimbursement

Participants and Non-Participants

Between 1974 and 1978

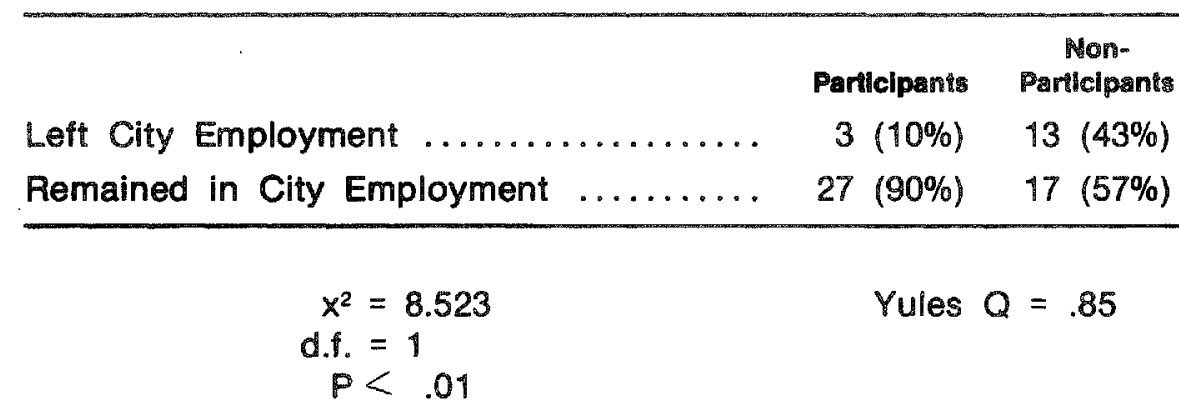

Significant differences exist between the two groups. A substantially larger proportion of non-participants $(43 \%)$ chose to leave city employment than is the case for participants $(10 \%)$. This indicates, for the survey city at least, that people who tend to remain in city employment also are likely to take advantage of the tuition reimbursement program.

The fourth research question dealt with the relationship between utilization of the program and upward mobility in the organization. To address this question the records of the subgroups not used for question three were examined.

TABLE 5

A Comparison of the Average Rates of Promotion Between Program Participants and Matched Pair Non-Participants

\begin{tabular}{|c|c|c|c|}
\hline & & $\begin{array}{l}\text { Program } \\
\text { Particlpants }\end{array}$ & $\begin{array}{c}\text { Non- } \\
\text { Participants }\end{array}$ \\
\hline $\bar{x}$ & $\ldots \ldots \ldots \ldots \ldots \ldots \ldots \ldots \ldots \ldots \ldots$ & .66 & .43 \\
\hline
\end{tabular}

t-test of differences between the means significant at .07 confidence level.

Promotions among participants ranged from 0 to 5. Promotions among non-participants ranged from 0 to 4 . The mean promotion rate for program participants was .66; the mean for non-participants was .43. This constitutes a $56 \%$ higher promotion rate for participants than for non-participants. The 
t-test of differences between means was of borderline significance at the .07 confidence interval. Clearly, participants experienced more promotions than non-participants.

\section{Conelusion}

The data clearly indicate that tuition reimbursement is a valuable fringe benefit from which both the city and its employees benefit. The city benefits because program participants seem to acquire requisite skills for advancement. The fact that promotions are forthcoming as a result of using the program is a positive incentive for employees to participate. The data also indicate that there is a strong relationship between program participation and the likelihood that persons will remain in the organization. Stated another way, tuition reimbursement seems to be a positive incentive for the type of person that the organization wishes to retain and advance.

Critics might argue that the findings are potentially skewed as a result of "creaming;" i.e. that management may direct favored employees into the program. If such were the case, the sample would be loaded on its face. Creaming does not occur in the city in question; program participation is by self-nomination. Generally, the respondents learned of the program by word of mouth from program participants.

From a managerial perspective, the findings suggest that a systematic program of creaming would positively affect the organization. The city in question would do well to incorporate tuition reimbursement into a systematic program of employee development.

Kaimen and Robey reasoned that program participation brings with it the expectation of advancement. They further reasoned that if such advancement is not forthcoming the employee-student may seek employment elsewhere. In this case the fear is unfounded because participants are rewarded and leave the organization much less often than non-participants. The fact is that the program most positively benefits persons who the city wishes to retain and advance. Thus, more tham providing the attendant general improvements in government service through increased professionalization, tuition reimbursement provides benefit to the city by reducing the costs involved in recruiting and training replacement employees.

There is no evidence, moreover, that participation in the program negatively affects job performance. To the contrary, the consensus among participants, non-participants and supervisors is that participation improves work performance.

Cost-conscious administrators must weigh the value of programs with regard to who benefits directly from them as well as the costs and benefits of the program in comparison with other programs which are under consideration for costs. These findings clearly indicate that the tuition 
assistance program directly benefits the most valued employees of the city. Secondly, these same employees ranked the program over other programs with direct economic impact upon them - parking and the payment of professional fees.

\section{NOTES}

The emphasis upon cutback management in public administration is manifested in a March/April Public Administration Review Article in which fully 12 of the recommended considerations dealt with personnel programs (Lewis and Logalbo: 1980).

2The study is quasi-experimental in the sense that two groups were selected at random from separate populations and compared. For a complete discussion of the quasi-experimental methodology, see Weiss (1972).

\section{REFRRENCES}

Foegen, J. H. (1973). "The High Cost of Innovative Employee Benefits." California Management Review (Spring): 184-188.

Kaimen, R. and D. Robey (1976). "Tuition Refund: Asset or Liability." Personnel Joumal (August): 389-399.

Ling, C. (1965). The Management of Personnel Relations. Homewood: Richard D. Irwin Inc.

Omera, J. (1970). Combating Knowledge Obsolescence: Employee Tuition Plan. New York: National Industrial Conference Board.

Lewis, C. and A. Logalbo (1980). "Cutback Principles and Practices: Checklist for Managers." Public Administration Review (March/April): 184-188.

Seybold, G. (1964). "What's New in Tuition-Aid Plans." The Conference Board Record.

Weiss, C. (1972). Evaluation Research. Englewood Cliffs: Prentice-Hall Inc.

Milwaukee Personnel Department Training Unit (1977). "Tuition Reimbursement in Employee Productivity and Aid: A Survey." Public Personnel Management (May/June): 166-172.

National Industrial Conference Board (1956). Tuition Aids Plans for Employees. New York: National Industrial Conferene Board. 